\title{
Economic Diversification and the State of Oil Dependency of UAE Stock Returns-An Analysis of ADX Indices 2014-2019
}

\author{
Dr. T.P.Ghosh ${ }^{1}$ \\ ${ }^{1}$ Professor of Accounting and Finance, Institute of Management Technology, Dubai \\ Correspondence: Dr. T.P.Ghosh, Professor of Accounting and Finance, Institute of Management Technology, Dubai, \\ E-mail: tpghosh@imt.ac.ae. ORCID iD: https://orcid.org/0000-0002-2282-0013
}

Received: September 18, 2019

Accepted: November 4, 2019

Online Published: November 6, 2019

doi:10.5430/afr.v8n4p199

URL: https://doi.org/10.5430/afr.v8n4p199

\begin{abstract}
Impact of commodity price risk on stock return remains an important forecasting parameters across stock markets of developed and emerging markets. In recent times the subdued oil price poses a challenge to the economic imbalance among oil producing countries, and thus non-oil diversification has been adopted as an economic solution. Amongst the GCC countries, the intensity of non-oil diversification has been found to be higher in the UAE which prompted to conduct a separate study of impact of oil price volatility on stock returns of Abu Dhabi Securities Market General Index and various sectoral indices. This study examines whether UAE stock returns are still associated with changes in oil price as reported in earlier research despite significant improvements in non-oil sector GDP contributions. The empirical assessment is based on weekly returns of the Abu Dhabi Stock Market General Index and four sectoral indices, namely, banking, industrial, energy and real estate in relation to variations in weekly WTI prices for the period between $1^{\text {st }}$ week of 2012 to $29^{\text {th }}$ week of 2019, i.e., for a period of 392 weeks applying Vector Error Correction model and Granger Causality test. It is found that there exists both long run and short run association between oil price volatility and stock return except model misspecification in respect of industrial and energy sectors arising out of serial correlation. Two lagged weekly oil price movements are found to be strong explanatory variables of stock returns.
\end{abstract}

Keywords: Abu Dhabi securities market, CUSUM test, Granger causality test, Gulf cooperation council, non-oil diversification, oil dependency, oil price volatility, Vector error correction model

\section{UAE Economy in the Low Oil Price Regime}

The issue of oil dependency of GCC countries (Note 1) has been widely researched by Alqattan and Alhayky (2016), Alhayki (2014), Arouri and Rault (2012), Arouri and Fouquau (2009), Arouri, Lahiani and Bellalah (2010), Cheikh , Naceur and Rault (2018), Dutta, Nikkinen and Rothovius (2017), and Vohra (2017) in the post-economic recession period (2009 onwards) in view of the protracted lower level of oil prices and resultant economic consequences. The weekly West Texas Intermediate (WTI) prices per barrel during the period of 2007-July 2019 (Figure 1) shows that declining oil prices during 2014-15 touched a low of $\$ 28.16$ per barrel in the $8^{\text {th }}$ week of 2016 (476th week of the weekly WTI price data series) but recovered to an average price level of $\$ 54.31$ per barrel post 2016. During this study period of 654 weeks covering the 2008-09 recession and the oil crisis of 2014, oil price per barrel averaged at a sub- $\$ 60$ level for many weeks. This caused significant budget deficits in various GCC countries and raised serious challenges to their economic stability during the low oil price regime. The oil crisis of 2014 as demonstrated in sharp fall of oil prices from a high of $\$ 105.52$ per barrel in the $27^{\text {th }}$ week of 2014 (392 ${ }^{\text {nd }}$ week of the weekly WTI price data series) was aggravated by a combination of multiple global events including a) economic slowdown in Europe, Japan, China and India, b) increased oil production by the US ( shale oil) and Canada leading to a reduction in their oil imports, and c) the decision of Saudi Arabia to continue stable production leading to oversupply. Rapid growth and expansion of China caused unprecedented demand for oil and price rise from \$23 per barrel to \$ 160 per barrel during 1999 -2008; So the slow down in the pace of growth has the significant price ramifications. Other large emerging economies like India and Brazil faced similar economic slow down that caused 2014 oil price fall. The low oil price regime continued for a long period which caused serious fiscal imbalance and economic impact in the GCC economies. Also Saudi Arabia's strategy to supply oil at low price relying upon its high oil reserve with an effort to force US and Canada to cut increased oil production did not yield the desired result. Price inelasticity of oil resulted in significant price changes with small shift in the balance of demand and supply. Because of interdependency of commodity market and stock 
market, low oil price had an overarching influence in stock market crash in the oil exporting countries. Thus decoupling of oil dependency became a strategic objective of MENAP oil exporting countries (Note 4) including the UAE.

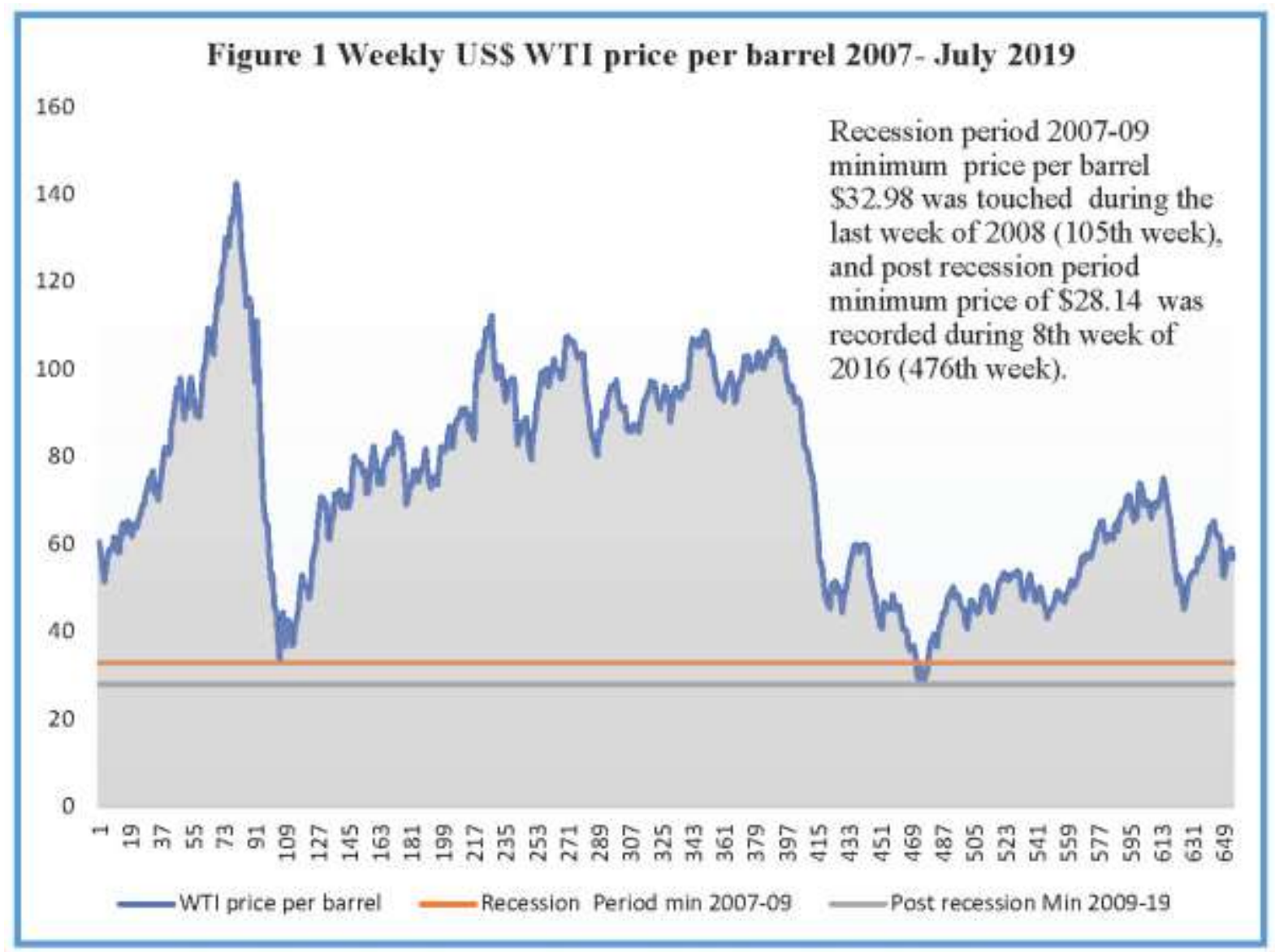

Data Source: https://www.investing.com/currencies/wti-usd-historical-data

High oil price has remained the driver of economic growth in the UAE (Note 2). Even amongst the GCC countries, overdependence of its government spending on oil revenue linked sources is perceived to be a major cause of economic risk. Against this backdrop of oil price volatility and production cuts instituted by the OPEC, the UAE government adopted an intensified strategy of non-oil diversification of economic activities that resulted in an average 10\% rise of non-oil contribution to GDP during 2012-2018, which reflects a major shift in the economic characteristics of the country (Figure 2 and Table 1). Diversification of the UAE's economy has been a strong pillar against which it can weather the adverse implications of continued fluctuations of the oil price. This structural change in contributions to GDP was made possible through investments in non-oil sectors and policy reforms facilitating FDI flows. The UAE better managed its fiscal deficit amongst all the GCC countries, eliminated energy (gasoline and diesel) subsidies, introduced VAT, and rationalized other taxes and fees.

Non-oil sector contribution to UAE's GDP was approximately $62.95 \%$ during $2007-14$, and had been shifted by about $10 \%$ in response to a severe decline in GDP primarily caused by oil price. However, the level of Government spending continued to depend on the level of oil price. This resulted in the volatility in oil price affecting the performance of the non-oil sector as well. Indeed, the non-oil sector showed a remarkable resiliency; it has recorded a stable growth pattern since the decline of the oil price in 2014. The Non-oil GDP per capita adjusted to the purchasing power in the UAE has improved significantly and grew by $11.9 \%$ during the period 2014-2016 [UAE Central Bank $(2018,2019)$; UAE Ministry of Economy (2018)]. 


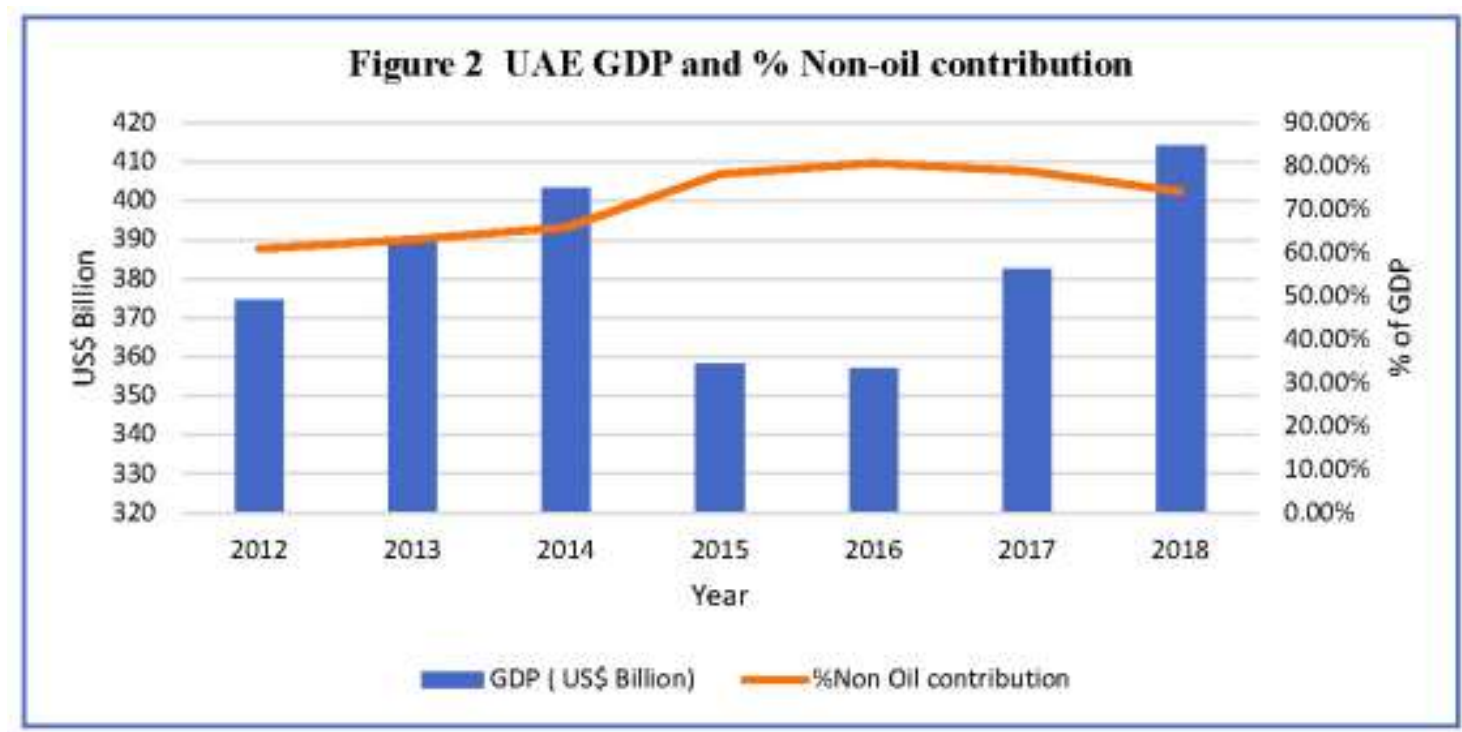

Data Sources: Annual Reports of UAE Central Bank (2018,2019), UAE Central Bank and Federal Competitiveness and Statistical Authority (2018), UAE Ministry of Economy (2018)

However, non-oil sectors advanced at a softer pace; growing by 1.3\% in 2018 compared to a growth of $1.9 \%$ in the previous year. Softer pace of growth was a reflection of the slowdown in some of the non-oil sectors [34]. Detailed of on non-oil sector growth in the UAE is presented in Table 1.

Diversification efforts combined with fiscal reforms of reduced subsidies for fuel and electricity and new taxes and fees have failed to counterbalance the fall in oil revenues. Thus, the UAE has set the non-oil GDP growth as an important key performance indicator in Vision 2021. The UAE Government approved an AED 50 billion (USD13.6 billion) economic stimulus package, with a fund of AED 20 billion (USD5.4 billion) allocated to the 2019 development package. This package aims at further reducing oil dependency of the UAE economy encouraging establishment of new industries and attracting foreign investments. The package includes ten economic initiatives including Abu Dhabi Accelerators and Advanced Industries Council to support the generation of more business activities and achieve higher share of private sector economic activity and to address the structural bottlenecks.

Table 1. Economic Growth by Sectors \%

\begin{tabular}{cccc}
\hline Sectors & Weight \% & \multicolumn{2}{c}{$\%$ Change } \\
\hline Agriculture & & 2017 & 2018 \\
Manufacturing & $1.0 \%$ & $3.3 \%$ & $7.1 \%$ \\
Construction & $12.1 \%$ & $5.0 \%$ & $1.9 \%$ \\
Electricity, gas and water supply & $4.0 \%$ & $-2.9 \%$ & $-2.3 \%$ \\
Wholesale and retail trade & $12.1 \%$ & $0.1 \%$ & $0.5 \%$ \\
Transportation and storage & $16.5 \%$ & $0.1 \%$ & $0.5 \%$ \\
Accommodation, food and service activities & $7.8 \%$ & $4.3 \%$ & $1.4 \%$ \\
Information and communication & $3.2 \%$ & $9.4 \%$ & $4.1 \%$ \\
Financial and insurance activities & $4.3 \%$ & $6.5 \%$ & $2.6 \%$ \\
Real estate activities & $12.2 \%$ & $1.4 \%$ & $0.8 \%$ \\
Professional, scientific and technical activities & $8.4 \%$ & $3.8 \%$ & $3.6 \%$ \\
Administrative and support service activities & $3.6 \%$ & $-1.8 \%$ & $1.4 \%$ \\
Public administration and defense & $2.5 \%$ & $-0.8 \%$ & $1.3 \%$ \\
Education & $7.7 \%$ & $0.4 \%$ & $0.3 \%$ \\
Human health and social work activities & $1.4 \%$ & $4.6 \%$ & $1.6 \%$ \\
Arts, recreation and other service activities & $1.7 \%$ & $0.0 \%$ & $1.7 \%$ \\
Activities of households as employers & $0.7 \%$ & $5.1 \%$ & $-0.1 \%$ \\
Non-oil GDP (Constant 2010 prices) & $0.8 \%$ & $5.7 \%$ & $3.5 \%$ \\
\hline
\end{tabular}

Source: Annual Report 2018, UAE Central Bank and Federal Competitiveness and Statistical Authority (2018) 
In view of the non-oil diversification efforts of the UAE government and resulting increases in contribution of non-oil sectors to the GDP, this study aims at evaluating whether the UAE has been successful in decoupling its economic performance from oil price fluctuations. The stock market being an important barometer of economic performance, any sign of economic decoupling should be identifiable through the movement of stock market indices vis a vis oil price movement. Based on this theorem, a stream of empirical research has used the co-integration of stock market movement and oil price as a sign of oil dependency. Researchers have also evaluated whether oil price movement "Granger causes movement in stock market indices".

This study is uniquely based on the Abu Dhabi Securities Market (ADX) general index and sectoral indices on the background of its non-oil diversification effort rather than general studies of GCC countries wherein non-oil diversification is of relatively higher. An IMF staff paper [ Olumuyiwa et al (2018)] described that GCC countries are differently impacted by lower oil price and the policy makers of various GCC countries differently attempted to address lower oil price. They observed that only the UAE could broadly balance between increases in revenues and restraint in spending. Also the UAE has been focusing for deepening the knowledge-driven economy, and has taken initiatives to increase competition, improve energy efficiency, and promotion of entrepreneurship. Cheikh et al [2018] documented heterogeneous reactions of stock markets across GCC countries to oil price change. They found significant asymmetries in the relationships between oil prices and stock markets in some GCC nations (Kuwait, Oman, and Qatar), but not in others (Bahrain, Saudi Arabia, and the UAE). This study draws motivation from these findings to conduct a separate study based on the Abu Dhabi stock market data because of its distinct non-oil diversification measures. Also the study period has been matched to the period of non-oil diversification in the UAE.

Figure 3 presents co-movement of weekly ADXG return and weekly change in WTI oil price (US\$) per barrel. Although strong sign of covariance has been observed between weekly return of stock indices and oil price change, post-2014 covariance is found to be weakening compared to covariance during 2007-2011 which may be considered as an early signal of decoupling of stock market volatility from oil price volatility. Induced by this early signal, this research study intends to assess whether non-oil diversification efforts that substantially changed the GDP structure of UAE helped to insulate the UAE stock market from the vagaries of oil market volatility.

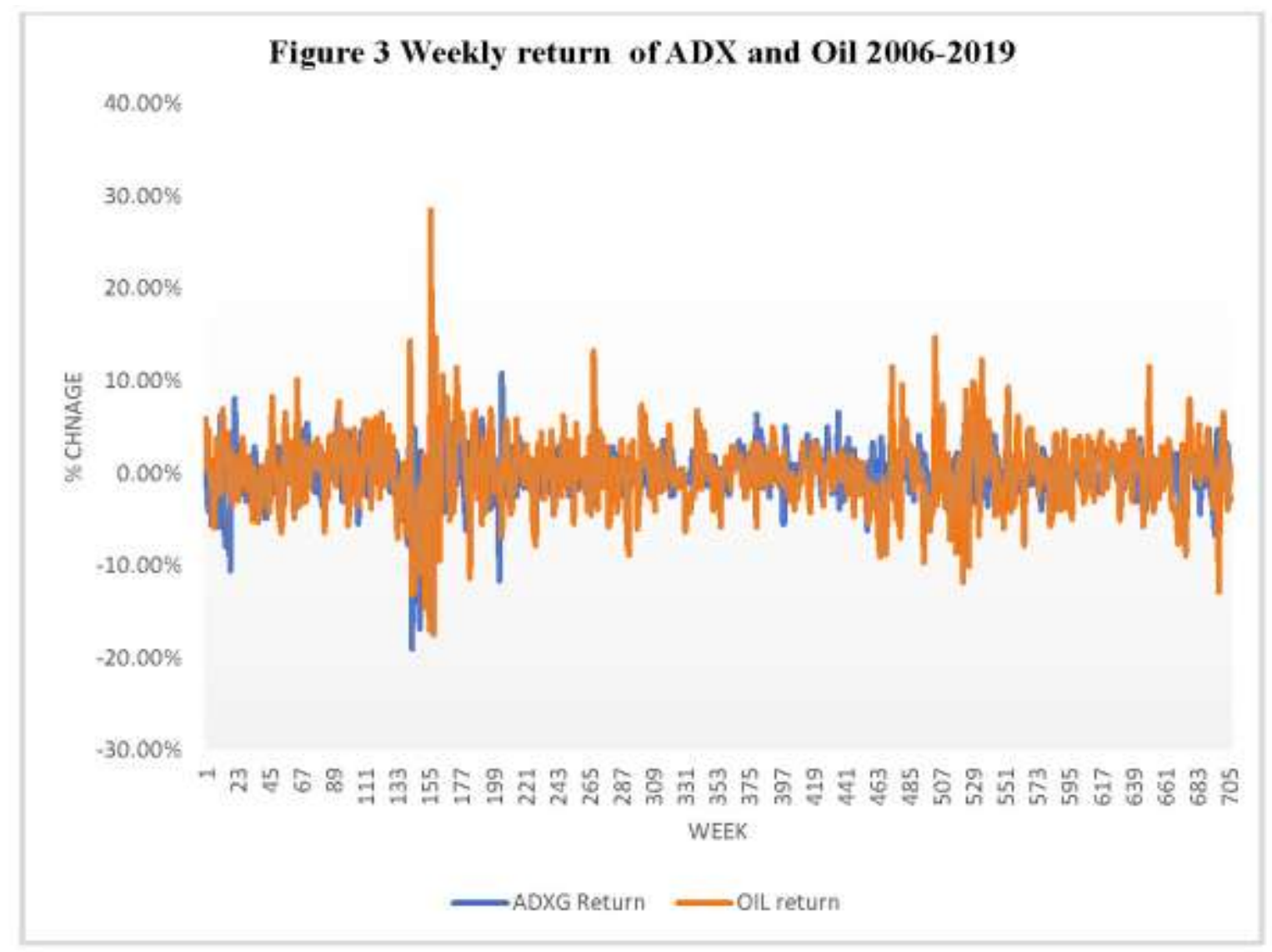

Data Sources: www.adx.com and https://www.investing.com/currencies/wti-usd-historical-data ; calculation by author 
Applying Vector Error Correction model and Granger Causality tests, it has been established that non-oil diversification could not decouple UAE stock returns. This study is based on data of Abu Dhabi Stock Exchange. Dubai Financial Market data are not mixed up in this analysis since oil dependency of Dubai emirate of the UAE is quite different. A recent Working Paper of IMF (2018) explains that that Saudi Arabia's equity market movements have a statistically significant impact on the equity markets in the rest of the GCC countries, after controlling for oil prices and global market developments. Specifically, a one percentage point increase in Saudi equity market returns is associated with a 0.06 percentage point increase in the rest of the GCC equity returns in the subsequent day. This study has not taken into account 'Saudi Arabia spillover effect' which is proposed to be covered in a separate research.

The layout of this paper is as follows: Section 2 covers a brief summary of relevant literature; data and methodology are explained in Section 3; Section 4 covers data analysis and Section 5 contains concluding remarks covering limitations and scope for further research.

\section{Literature Review}

Hamilton (2013) surveyed key post-World War II oil price shocks covering Suez Crisis of 1956-57, the OPEC oil embargo of 1973-1974, the Iranian revolution of 1978-1979, the Iran-Iraq War initiated in 1980, the first Persian Gulf War in 1990-91, the oil price spike of 2007-2008, and also other minor disturbances. His research underpinned the understanding of economic consequences of oil price shocks. Earlier Hamilton (1983, 1996,2009) studied the differential impact of oil price shocks on US economies and policy implications thereof. In particular, his research inter alia highlighted why US consumers responded so little when the price of oil moved up from \$41 per barrel in July 2004 to $\$ 65$ in August 2005 (a 59\% increase), but they responded quite differently to increase in oil price from $\$ 72$ in August 2007 to $\$ 134$ (an 86\% increase) in June 2008.

Also, the growing body of literature provided evidence on varied features of empirical relationship between oil price shocks and GDP. Hamilton (1983) found a statistically significant relationship between changes in oil prices and changes in real GNP and unemployment in the US economy during 1948-1973. He observed that seven out of the previous eight recessions had been preceded by a dramatic increase in crude oil prices. Mork (1989) found that oil price increases have more impact on economy than oil price decreases. He expanded on Hamilton's (1983) study by incorporating data from the 1980s into his analysis and found that positive oil price shocks had negative effects on output, while negative oil price shocks did not have expansionary effects on output. His further work [ Mork et al (1994)] highlighted the economic responses to both positive and negative oil price shocks in seven OECD countries and showed that correlations with positive oil price shocks and output were negative and significant for most of the countries, while correlations with negative oil price shocks were positive. Dotsey and Reid (1992) observed that oil price change impacted GDP by 5-6\%. Hooker (1996) also confirmed Hamilton's results and indicated that oil price changes had negative effects on the growth of US GDP during the period between 1948-1972. He observed that the OPEC price increases had significant impacts, while the effects of the price declines of the 1980s are smaller and harder to characterize. These results have potentially important implications for the large body of research which utilizes oil prices as an instrumental or explanatory variable.

Following the works by Chen et al (2018) that identified oil price movement as a risk factor for stock price and of Jones and Kaul (1996) that analyzed the reaction of international stock markets, a substantial body of research work examined the effect of change in oil price on stock return. They examined the impact of oil price change on shocks in stock markets in the US, Canada, UK, and Japan. They concluded that the effects of oil shocks on the US and Canadian stock markets can be explained by their effects on current and future real cash flows. However, real cash flows and expected return proxies could not explain the fluctuations on the stock markets in Japan and the UK. The postwar oil shocks seemed to have generated volatility in the stock markets. Sadorsky (1999) found that post-1986 oil price movements explain a larger fraction of the forecast error variance in real stock returns than do interest rates. He observed that oil price volatility shocks have asymmetric effects on the economy. Sadorsky (1999) showed that an oil price shock has a negative and statistically significant initial impact on stock returns. In another paper, Basher and Sadorsky (2006) studied the impact of oil price changes on a large set of emerging stock market returns and found strong evidence oil price risk impact on stock return in emerging markets.

Using a multivariate vector-autoregression approach, Papapetrou (2001) attempted to explain the dynamic relationship among oil prices, real stock prices, interest rates, real economic activity and employment in Greece. He observed that changes in oil price affect real economic activity and employment. Also, oil prices are important in explaining stock price movements. Hammoudeh and $\mathrm{Li}$ (2005) found a positive association between oil prices and equity returns with respect to oil producing countries, but a negative association with the broad-based MSCI World Index. They 
examined and compared the oil sensitivity of equity return of non-Gulf, oil producing countries (e.g. Mexico and Norway) and two major oil-sensitive industries of the US (e.g. oil and transportation). They concluded that the oil price growth leads the stock returns of the oil-exporting countries and the US oil-sensitive industries. Thus, investors view the systematic risk more importantly than the oil sensitivity in pricing those oil-sensitive returns, regardless of the direction of the world capital market. By applying Vector Autoregression (VAR) models and bivariate Granger causality tests, Feride (2015) showed that both symmetric and positive oil price shocks decrease industrial production, money supply, and imports while the negative oil price shocks increase imports. Sonenshine and Cauvel (2017) explored how the magnitude of crude oil price changes affect the stock market returns and variances of key production, banking and consuming segments of the US economy. They provided explanations for the asymmetric responses to positive and negative oil shocks found in key sectors of the US economy.

In the context of stock markets of GCC countries, Maghyereh and Al-Kandari (2007) showed that in the long-run oil prices impact the stock price indices. Arouri et al (2010) examined short-term links between oil prices and stock markets in GCC countries using data from June 2005 to October 2008. They found that stock market returns react significantly to oil price changes in Qatar, Oman, Saudi Arabia, and the UAE. Also, relationships between oil prices and stock markets in these countries are nonlinear and switch according to the oil price values. However, for Bahrain and Kuwait they found that oil price changes do not affect stock market returns.

Alhayki (2014) examined the impact of oil price on stock market returns of GCC countries by applying wavelet analysis model on monthly data from May 2005 to December 2011. The results of Granger causality of MODWT multi-resolution analysis show that in the long run a strong bidirectional causal relationship exists between oil prices and each of the stock market returns in the GCC region. Using recent bootstrap panel cointegration techniques and seemingly unrelated regression (SUR) methods, Arouri and Rault (2012) observed that there is evidence for cointegration between oil prices and stock markets in GCC countries, while the SUR results indicate that oil price increases have a positive impact on stock prices, except in Saudi Arabia.

Alqattan and Alhayky (2016) studied the relationship between oil prices and the stock market price in GCC for the period between 2006-2015 and found that oil price fluctuations play an important role in determining the stock market prices in GCC countries in the short run. This study also concluded that in the long run stock market price is not sensitive to oil price fluctuations in GCC countries except in Oman. Dutta et al. (2017) report a positive, significant relationship between oil prices and realized stock market uncertainties even after controlling for global stock market uncertainty in Saudi Arabia, Kuwait, the UAE, and Qatar. Applying Johansen Cointegration test on Box Cox transformed data of oil price and seven stock market indices of GCC countries, Ghosh (2017) found that oil price and GCC stock markets are co-integrated. This study explained that efforts to reduce oil dependency in GCC countries is yet to result in decoupling of financial markets from oil price cyclicality. Vohra (2017) explained the oil dependency of GCC economies and showed that there is a link between economic growth and oil price changes, in particular to the current account balances of GCC countries.

Cheikh et al. (2018) observed the presence of stock market returns' asymmetric reactions in some GCC countries, but not for others. They found that negative oil price changes exert larger impacts on stock returns than positive oil price changes in Kuwait's case. When considering the asymmetry with respect to the magnitude of oil price variation, they found that Oman's and Qatar's stock markets are more sensitive to large oil price changes than to small ones.

\section{Data and Methodology}

\subsection{Research Hypothesis and Study Period}

This study intends to test whether UAE stock returns are still associated with changes in oil price despite improvements in non-oil sector GDP contributions.

Null hypothesis $\left(H_{0}\right)$ : Changes in UAE Stock market returns are independent of oil price changes in the aftermath of the 2014 oil price shock

Alternative Hypothesis (H1): Changes UAE Stock market returns continued to be influenced by oil price changes.

The change stock return of a week is attempted to be explained by oil price changes in earlier week(s) and also stock returns of earlier week(s). In Section 3.4, VAR lag order selection has been explained. Explanatory variables are developed using Least Square (Gauss-Newton/ Marquardt) steps (Table 4).

For empirical assessment of this relationship, weekly returns of the Abu Dhabi Stock Market General Index (ADXG) and four sectoral indices (Note 3), namely, banking (ADBF), real estate (ADRE), industrial (ADCT), and energy $(\mathrm{ADEG})$ are separately studied in relation to variations in weekly WTI prices for the period between $2012-29^{\text {th }}$ 
week of 2019, i.e., for a period of 392 weeks (out of the 654 weeks shown in Figure 1). These selected 392 weeks cover the 2014 oil crisis and the era of non-oil diversification in the UAE. Most of the recent studies cover GCC economies, however the dimensions and intensity of non-oil diversification in the UAE are different from other GCC countries. Weekly indices data are sourced from the Abu Dhabi Securities exchange (www.adx.ae) and weekly WTI prices per barrel from a reputable online source, namely, investing.com (https://www.investing.com/currencies/wti-usd-historical-data). Data analysis is carried out using EViews software. Tables 2- 7 and Appendix A are based on the data sets developed based on weekly WTI oil price data sourced from investing.com and data of various stock indices sourced from Abu Dhabi Stock Exchange.

\subsection{Vector Error Correction Model}

The vector autoregressive (VAR) model is a general framework used to describe the dynamic interrelationship among stationary variables. The vector error correction (VEC) model is just a special case of the VAR for variables that are stationary in their differences (i.e., I(1)). If non-stationary but I(1) time series are cointegrated, the VEC model is applied to examine both short-run and long-run dynamics of the series. The conventional VEC model equation for cointegrated series is:

$\Delta y_{t}=\beta_{0+} \sum_{i=1}^{n} \beta_{i} \Delta y_{t-i}+\sum_{i}^{n} \delta_{i} \Delta x_{t-i}+\varphi z_{t-1}+u_{i} \quad$ Eq. 1

$\mathrm{y}=$ Weekly ADXG or sectoral indices

$\mathrm{x}=$ Weekly WTI prices in US\$ per barrel

$\mathrm{z}=$ Error correction term $(\mathrm{ECT})$

The significant t-statistic on the parameters of ECT indicate existence of the long run relationship and long run causality between the variables. It is a restricted VAR designed for use with nonstationary series which are cointegrated. In the VEC model there are in-built cointegration relations in the specification such that the model restricts the long-run behaviour of the endogenous variables to converge to their cointegrating relationships while allowing for short-run adjustment dynamics. The cointegration term is defined as ECT which relates to the fact that the deviation from long-run equilibrium is corrected gradually through a series of partial short-run adjustments.

ECT is Ordinary Least Square (OLS) residuals from the following long run cointegrating regression:

$y_{t}=\beta_{0}+\beta_{1} x_{t}+\varepsilon_{t} \quad$ Eq. 2

and is defined as -

$z_{t-1}=E C T_{t-1}=y_{t-1} \beta_{0}-\beta_{1} x_{t-1} \quad$ Eq. 3

The coefficient of ECT, $\varphi$, is the speed of adjustments - it measures the speed at which y (return of stock indices) returns to equilibrium after a change in $\mathrm{x}$, i.e., weekly oil price.

\subsection{Unit Root Test}

At first, stationary of variables should be ensured to avoid spurious regression. In this section stationary of variables is checked by applying Augmented Dickey Fuller (ADF), Dickey Fuller GLS (ERS) and Kwiatkowski-Philips-Schmidt-Shin (KPSS) tests. ADF and ERS tests showed that under the null hypothesis of a unit root; their outputs reported MacKinnon lower-tail critical and p-values for these tests. But the KPSS test differs from other unit root tests described here - in those the series are assumed to be stationary under the null hypothesis, and the KPSS output only provided the asymptotic critical values tabulated by KPSS.

Null Hypothesis: Series ADXG, ADRE, OIL, ADBF, ADID and ADEG have unit root (meaning series is non-stationary). At 5\% level, null hypothesis could not be rejected. Thus, first difference of all series are derived as:

$$
\begin{gathered}
\text { First Difference of weekly indices series }=\frac{L N y_{t}}{L N y_{t-1}} \\
\text { First Difference of weekly WTI prices series }=\frac{L N x_{t}}{L N x_{t-1}}
\end{gathered}
$$


Table 2. Unit Root Tests

\begin{tabular}{|c|c|c|c|c|c|c|c|}
\hline \multirow[b]{2}{*}{$\begin{array}{c}\text { Tests \& } \\
\text { Observations }\end{array}$} & & \multicolumn{2}{|c|}{$A D X G$} & \multicolumn{2}{|c|}{$A D R E$} & \multicolumn{2}{|c|}{$A D B F$} \\
\hline & & Level & $\begin{array}{c}\text { First } \\
\text { Difference }\end{array}$ & Level & $\begin{array}{c}\text { First } \\
\text { Difference }\end{array}$ & Level & $\begin{array}{c}\text { First } \\
\text { Difference }\end{array}$ \\
\hline $\mathrm{ADF}$ & $\begin{array}{l}\text { t statistic } \\
\text { Prob. } *\end{array}$ & $\begin{array}{l}-2.0246 \\
(0.2762)\end{array}$ & $\begin{array}{c}-17.5230 \\
(0.0000)\end{array}$ & $\begin{array}{c}-2.757 \\
(0.1805)\end{array}$ & $\begin{array}{c}-11.6258 \\
(0.0000)\end{array}$ & $\begin{array}{l}-1.7354 \\
(0.4126)\end{array}$ & $\begin{array}{c}-17.7289 \\
(0.0000)\end{array}$ \\
\hline $\begin{array}{l}\text { No. adjusted } \\
\text { Observations }\end{array}$ & & 392 & 391 & 392 & 388 & 392 & 391 \\
\hline GLS(ERS) & $\begin{array}{l}\text { t statistic } \\
\text { Prob.** }\end{array}$ & 0.3423 & -15.9909 & -0.7395 & -4.9427 & 0.4529 & -16.2169 \\
\hline $\begin{array}{l}\text { No. adjusted } \\
\text { Observations }\end{array}$ & \multicolumn{6}{|c|}{ Observations } & 391 \\
\hline KPSS & $\begin{array}{l}\text { t statistic } \\
\text { Prob.** }\end{array}$ & 1.4486 & 0.2309 & 0.4068 & 0.2654 & 1.0617 & 0.1839 \\
\hline \multicolumn{8}{|l|}{ Observations } \\
\hline & & \multicolumn{2}{|c|}{ ADEG } & \multicolumn{2}{|c|}{ ADCT } & \multicolumn{2}{|c|}{ WTI OIL } \\
\hline Tests \& & & Level & First & Level & First & Level & First \\
\hline Observations & & \multicolumn{2}{|c|}{ Difference } & \multicolumn{2}{|c|}{ Difference } & \multicolumn{2}{|c|}{ Difference } \\
\hline $\mathrm{ADF}$ & $\begin{array}{l}\text { t statistic } \\
\text { Prob. }{ }^{*}\end{array}$ & $\begin{array}{l}-2.0125 \\
(0.2815)\end{array}$ & $\begin{array}{c}-17.4202 \\
(0.0000)\end{array}$ & $\begin{array}{l}-1.4107 \\
(0.5778)\end{array}$ & $\begin{array}{r}-15.7517 \\
(0.0000)\end{array}$ & $\begin{array}{l}-1,6321 \\
(0.4652)\end{array}$ & $\begin{array}{l}-144773 \\
(0.0000)\end{array}$ \\
\hline $\begin{array}{l}\text { No. adjusted } \\
\text { Observations }\end{array}$ & & 392 & 391 & 392 & 391 & 392 & 391 \\
\hline GLS(ERS) & $\begin{array}{l}\text { t statistic } \\
\text { Prob.** }\end{array}$ & 0.3423 & -17.4420 & -0.9819 & -15.0990 & -0.4547 & -3.2479 \\
\hline $\begin{array}{l}\text { No. adjusted } \\
\text { Observations }\end{array}$ & & 392 & 391 & 392 & 391 & 392 & 387 \\
\hline KPSS & $\begin{array}{l}\text { t statistic } \\
\text { Prob.*** }\end{array}$ & 0.2944 & .0922 & 0.4203 & 0.3109 & 1.4475 & 0.1050 \\
\hline $\begin{array}{l}\text { No. adjusted } \\
\text { Observations }\end{array}$ & & 393 & 392 & 393 & 392 & 393 & 392 \\
\hline
\end{tabular}

*Mackinnon (1996) one-sided p value

Augmented Dickey Fuller Test (ADF)

No. of observations

392

391

388

Test Critical Values

\begin{tabular}{llrl}
$1 \%$ Level & -3.446819 & -3.446862 & -3.446992 \\
$5 \%$ Level & -2.868694 & -2.868713 & -2.868771 \\
\hline
\end{tabular}

** Mackinnon (1996)

Ellott-Rothenberg-Stock DF-GLS Test [ GLS(ERS)]

No. of observations

392

391

387

386

Test Critical Values

$1 \%$ Level

-2.570875
-1.941634

$-2.570890$

$-2.570951$

$-2.570967$

$-1.941636$

$-1.941644$

$-1.941646$ 
Kwiatkowski-Phillips-Schmidt-Shin ( 1992, Table 1)

Kwiatkowski-Phillips-Schmidt-Shin test statistic

$\begin{array}{ccccc}\text { No. of observations } & 392 & 391 & 387 & 386 \\ \text { Test Critical Values } & & & & \\ 1 \% \text { Level } & 0.739000 & 0.739000 & -2.570951 & -2.570967 \\ 5 \% \text { Level } & 0.463000 & 0.463000 & -1.941644 & -1.941646\end{array}$

At first difference, null hypothesis is rejected since $p$ value $\leq 5 \%$ applying ADF, GLS(ERS) and KPSS tests. Test results, presented in Table 2, clearly indicate the presence of a unit root for all the series in levels and a rejection for the series in first-differences, providing evidence of an I(1) behaviour.

\subsection{Lag Selection}

To estimate the Johansen cointegration model, the optimal interval of variables must be provided at first. Thus, LR test and information criterion are used to identify the optimal interval based on "lag length" functionality of Eviews software. Summary of the analysis is presented in Table 3 below, showing the specific rows in which minimum lag has been selected. Based on the result of VAR Lag Order Selection criteria, 2 lags are selected for all series.

Table 3. VAR Lag Order Selection

VAR Lag Order Selection Criteria

Endogenous variables : OIL ADXG Exogenous variables : C

Sample : $1393 \quad$ Included observations : 385

\begin{tabular}{cccccccc}
\hline Data Series & Lag & $\log L$ & $L R$ & $F P E$ & $A I C$ & $S C$ & $H Q$ \\
\hline LN(ADXG) & 2 & 1684.279 & $\mathbf{2 7 . 7 8 2 4 7 *}$ & $\mathbf{5 . 6 0 e - 0 7 *}$ & $\mathbf{- 8 . 7 2 0 2 0 1 *}$ & $\mathbf{- 8 . 6 1 7 3 2 0} *$ & $\mathbf{- 8 . 6 7 9 3 9 4 *}$ \\
LN(OIL) & & & & & & & \\
LN(ADBF) & 1 & 1599.504 & 34.01127 & $8.52 \mathrm{e}-07$ & -8.299500 & $\mathbf{- 8 . 2 3 7 7 7 1} *$ & -8.275015 \\
LN(OIL) & 2 & 1610.469 & $21.64420^{*}$ & $8.22 \mathrm{e}-07^{*}$ & $-8.335775^{*}$ & -8.232894 & $-8.294968^{*}$ \\
LN(ADCT) & 1 & 1658.412 & 39.95150 & $6.27 \mathrm{e}-07$ & -8.606311 & $\mathbf{- 8 . 5 4 4 5 8 2 *}$ & $\mathbf{- 8 . 5 8 1 8 2 7} *$ \\
LN(OIL) & 2 & 1663.244 & $\mathbf{9 . 5 3 8 8 8 8 *}$ & $6.24 \mathrm{e}-07$ & $\mathbf{- 8 . 6 1 0 6 4 6 *}$ & -8.507765 & -8.569839 \\
LN(ADEG) & 1 & 1403.492 & 42.61062 & $2.37 \mathrm{e}-06$ & -7.278606 & $\mathbf{- 7 . 2 1 6 8 7 7 *}$ & -7.254122 \\
LN(OIL) & 2 & 1413.977 & $20.69548^{*}$ & $2.29 \mathrm{e}-06^{*}$ & $-7.312378^{*}$ & -7.209497 & $\mathbf{- 7 . 2 7 1 5 7 1 *}$ \\
LN(ADRE) & 1 & 1350.917 & 33.58121 & $3.11 \mathrm{e}-06$ & -7.004779 & $\mathbf{- 6 . 9 4 3 0 5 0 *}$ & $\mathbf{- 6 . 9 8 0 2 9 4 *}$ \\
LN(OIL) & 4 & 1364.111 & $20.21824 *$ & $3.09 \mathrm{e}-06$ & -7.010995 & -6.825809 & -6.937542 \\
& 5 & 1368.943 & 9.386175 & $3.08 \mathrm{e}-06$ & $-7.015326^{*}$ & -6.788987 & -6.925550 \\
\hline
\end{tabular}

*indicates lag order selected by the criterion

LR : sequential modified LR test statistic ( each test at $5 \%$ level)

FPE : Final prediction error

AIC : Akaike information error

$\mathrm{SC}:$ Schwarz information criterion

HQ : Hannan - Quinn Information criterion

\subsection{Cointegration Test}

Johansen cointegration test for five pairs, i.e., LN(ADXG) LN(OIL), LN(ADBF) LN(OIL), LN(ADCT) LN(OIL), LN(ADEG) LN(OIL), and LN(ADRE) LN(OIL) are carried out using Unrestricted Cointegration Rank test (Trace) and Unrestricted Cointegration Rank test (Maximum Eigenvalue). Test results are presented in Appendix 1. All series have two cointegrating equations and a null hypothesis that there is no cointegration is rejected at $5 \%$ level based on Mackinnon-Haugh-Michelis (1999) p-values. Normalized cointegrating coefficients are negative and lie 
within -1 and 0 . This implies even if there are shocks in the short run, they may affect the movement of the individual series, but would converge in the long run. Based on result of unit root tests, lag selections, and cointegration tests as shown in Sections 3.3-3.5, the application of VEC model appears to be the appropriate choice as a method of data analysis.

\section{Data Analysis}

Results of application of VEC model on the five data series are presented in Table 4. Value of C(1) of series are negative and significant. This implies that if there is departure from equilibrium in one direction it would be pulled back. Value of $\mathrm{C}(1)$ signifies the speed of correction - it is value of $\mathrm{ECT}_{\mathrm{t}-1}$ (Eq.3). ECT should be in negative number, and the positive value means explosive and not reasonable. For example, if the $\mathrm{ECT}_{\mathrm{t}-1}$ estimated coefficient is -0.93 (as in the case of Series 1), the estimated coefficient indicates that about $93 \%$ of this disequilibrium is corrected within one week since weekly data has been used in this study. This also implies that all explanatory variables Granger causes to explain changes in the indices. The outputs of the VEC model ( Table 4) are further tested by applying coefficients diagnostics (Wald Test), residual diagnostics (Serial correlation LM test), and stability diagnostics (Recursive estimates - CUSUM test).

Table 4. Output of VEC Model: Least Squares ( Gauss-Newton/ Marquardt Steps)

\begin{tabular}{|c|c|c|c|c|}
\hline \multirow{4}{*}{\multicolumn{3}{|c|}{$\begin{array}{c}\text { Series 1: LN(ADXG) LN(OIL) } \\
\text { Dependent Variable : D(ADXG) } \\
\text { Sample } 4392 \\
\text { Included observations : } 389 \text { after } \\
\text { adjustments }\end{array}$}} & \multirow{4}{*}{\multicolumn{2}{|c|}{$\begin{array}{c}\mathrm{D}(\mathrm{ADXG})=\mathrm{C}(1) \times(\mathrm{ADXG}(-1)- \\
0.311902923454 \times \mathrm{OIL}(-1)-0.00233296158938) \\
+\mathrm{C}(2) \times \mathrm{D}(\mathrm{ADXG}(-1))+\mathrm{C}(3) \times \mathrm{D}(\mathrm{ADXG}(-2))+ \\
\mathrm{C}(4) \times \mathrm{D}(\mathrm{OIL}(-1))+\mathrm{C}(5) \times \mathrm{D}(\mathrm{OIL}(-2))+\mathrm{C}(6))\end{array}$}} \\
\hline & & & & \\
\hline & & & & \\
\hline & & & & \\
\hline & Coefficient & Std. Error & t-statistic & Prob. \\
\hline $\mathrm{C}(1)$ & -0.935281 & 0.076621 & -12.20661 & 0.0000 \\
\hline $\mathrm{C}(2)$ & 0.056362 & 0.062160 & 0.906715 & 0.3651 \\
\hline $\mathrm{C}(3)$ & 0.020730 & 0.048440 & 0.427943 & 0.6689 \\
\hline $\mathrm{C}(4)$ & -0.267934 & 0.030476 & -8.791641 & 0.0000 \\
\hline $\mathrm{C}(5)$ & -0.091323 & 0.028760 & -3.175310 & 0.0016 \\
\hline$C(6)$ & -0.000123 & 0.001074 & -0.114493 & 0.9089 \\
\hline \multicolumn{2}{|c|}{ R-Squared } & 0.473218 & Mean Dependent var & 0.000101 \\
\hline \multicolumn{2}{|c|}{ Adjusted R-squared } & 0.466341 & S.D. dependent var & 0.028991 \\
\hline \multicolumn{2}{|c|}{ S.E. of regression } & 0.021179 & Akaike info criterion & -4.856349 \\
\hline \multicolumn{2}{|c|}{ Sum square residual } & 0.171788 & Schwarz criterion & -4.795214 \\
\hline \multicolumn{2}{|c|}{ Log likelihood } & 950.5599 & Hannan- Quinn Criterion & -4.832112 \\
\hline \multicolumn{2}{|c|}{ F-statistic } & 68.81113 & Durbin -Watson stat & 2.015466 \\
\hline \multicolumn{2}{|c|}{ Prob ( F-Statistic) } & 0.000000 & & \\
\hline \multirow{4}{*}{\multicolumn{3}{|c|}{$\begin{array}{l}\text { Series } 2 \text { : LN(ADBF) LN OIL) } \\
\text { Dependent Variable : D(ADBF) } \\
\text { Sample } 4392 \\
\text { Included observations : } 389 \text { after } \\
\text { adjustments }\end{array}$}} & \multirow{4}{*}{\multicolumn{2}{|c|}{$\begin{array}{c}\mathrm{D}(\mathrm{ADBF})=\mathrm{C}(1) \times(\mathrm{ADBF}(-1)- \\
0.314749198763 \times \mathrm{OIL}(-1)-0.00291416845776) \\
+\mathrm{C}(2) \times \mathrm{D}(\mathrm{ADBF}(-1))+\mathrm{C}(3) \times \mathrm{D}(\mathrm{ADBF}(-2))+ \\
\mathrm{C}(4) \times \mathrm{D}(\mathrm{OIL}(-1))+\mathrm{C}(5) \times \mathrm{D}(\mathrm{OIL}(-2))+\mathrm{C}(6)\end{array}$}} \\
\hline & & & & \\
\hline & & & & \\
\hline & & & & \\
\hline & Coefficient & Std. Error & t-statistic & Prob. \\
\hline $\mathrm{C}(1)$ & -1.052291 & 0.080543 & -13.06498 & 0.0000 \\
\hline $\mathrm{C}(2)$ & 0.142163 & 0.064294 & -2.211140 & 0.0276 \\
\hline $\mathrm{C}(3)$ & 0.085713 & 0.048865 & 1.754084 & 0.0802 \\
\hline $\mathrm{C}(4)$ & -0.267379 & 0.035724 & -7.484548 & 0.0000 \\
\hline $\mathrm{C}(5)$ & -0.078961 & 0.033640 & -2.347233 & 0.0194 \\
\hline$C(6)$ & 5.82E-05 & 0.001285 & 0.045278 & 0.9639 \\
\hline
\end{tabular}




$\begin{array}{cccc}\text { R-Squared } & 0.479568 & \text { Mean Dependent var } & 3.92 \mathrm{E}-05 \\ \text { Adjusted R-squared } & 0.472774 & \text { S.D. dependent var } & 0.034901 \\ \text { S.E. of regression } & 0.025342 & \text { Akaike info criterion } & -4.497433 \\ \text { Sum square residual } & 0.245962 & \text { Schwarz criterion } & -4.436298 \\ \text { Log likelihood } & 880.7506 & \text { Hannan- Quinn Criterion } & -4.473196 \\ \text { F-statistic } & 70.58552 & \text { Durbin -Watson stat } & 2.023096 \\ \text { Prob ( F-Statistic) } & 0.00000 & & \end{array}$

\section{Series 3 : LN(ADCT) LN(OIL)}

Dependent Variable : D(ADCT) Sample 4392

Included observations : 389 after adjustments

\begin{tabular}{|c|c|c|c|c|}
\hline & Coefficient & Std. Error & t-statistic & Prob. \\
\hline $\mathbf{C}(\mathbf{1})$ & -0.517928 & 0.062609 & -8.272446 & 0.0000 \\
\hline $\mathrm{C}(2)$ & -0.208421 & 0.058730 & -3.548825 & 0.0004 \\
\hline $\mathrm{C}(3)$ & -0.163674 & 0.049053 & -3.336651 & 0.0009 \\
\hline $\mathrm{C}(4)$ & -0.219874 & 0.035953 & -6.115554 & 0.0000 \\
\hline $\mathrm{C}(5)$ & -0.094179 & 0.031804 & -2.961194 & 0.0003 \\
\hline$C(6)$ & $3.08 \mathrm{E}-05$ & 0.001184 & -0.026025 & 0.9793 \\
\hline \multicolumn{2}{|c|}{ R-Squared } & 0.374945 & Mean Dependent var & 7.01E-06 \\
\hline \multicolumn{2}{|c|}{ Adjusted R-squared } & 0.366785 & S.D. dependent var & 0.029349 \\
\hline \multicolumn{2}{|c|}{ S.E. of regression } & 0.023354 & Akaike info criterion & -4.660782 \\
\hline \multicolumn{2}{|c|}{ Sum square residual } & 0.208894 & Schwarz criterion & -4.599647 \\
\hline \multicolumn{2}{|c|}{ Log likelihood } & 912.5222 & Hannan- Quinn Criterion & -4.636546 \\
\hline \multicolumn{2}{|c|}{ F-statistic } & 45.94928 & \multirow[t]{2}{*}{ Durbin -Watson stat } & \multirow[t]{2}{*}{2.068107} \\
\hline \multicolumn{2}{|c|}{ Prob ( F-Statistic) } & 0.000000 & & \\
\hline \multicolumn{3}{|c|}{ Series 4 : LN(ADEG) LN(OIL) } & \multirow{4}{*}{\multicolumn{2}{|c|}{$\begin{array}{c}\mathrm{D}(\mathrm{ADEG})=\mathrm{C}(1) \times(\mathrm{ADEG}(-1)- \\
0.756942976513 \times \mathrm{OIL}(-1)-0.00227157922241) \\
+\mathrm{C}(2) \times \mathrm{D}(\mathrm{ADEG}(-1))+\mathrm{C}(3) \times \mathrm{D}(\mathrm{ADEG}(-2))+ \\
\mathrm{C}(4) \times \mathrm{D}(\mathrm{OIL}(-1))+\mathrm{C}(5) \times \mathrm{D}(\mathrm{OIL}(-2))+\mathrm{C}(6)\end{array}$}} \\
\hline \multirow{3}{*}{\multicolumn{3}{|c|}{$\begin{array}{l}\text { Dependent Variable : D(ADEG) } \\
\text { Sample } 4392 \\
\text { Included observations : } 389 \text { after } \\
\text { adjustments }\end{array}$}} & & \\
\hline & & & & \\
\hline & & & & \\
\hline & Coefficient & Std. Error & t-statistic & Prob. \\
\hline $\mathrm{C}(1)$ & -0.746785 & 0.074397 & -10.03784 & 0.0000 \\
\hline $\mathrm{C}(2)$ & -0.043731 & 0.063408 & -0.689674 & 0.4908 \\
\hline $\mathrm{C}(3)$ & -0.061537 & 0.050116 & -1.227888 & 0.2202 \\
\hline $\mathrm{C}(4)$ & -0.497823 & 0.064817 & -7.680397 & 0.0000 \\
\hline$C(5)$ & -0.144451 & 0.059538 & -2.426210 & 0.0157 \\
\hline$C(6)$ & -0.000214 & 0.002240 & 0.095588 & 0.9239 \\
\hline & quared & 0.426854 & Mean Dependent var & 0.000169 \\
\hline $\mathrm{Adj}$ & R-squared & 0.419372 & S.D. dependent var & 0.057978 \\
\hline & egression & 0.044179 & Akaike info criterion & -3.385846 \\
\hline Sun & re residual & 0.747522 & Schwarz criterion & -3.324711 \\
\hline & relihood & 664.5470 & Hannan- Quinn Criterion & -3.361609 \\
\hline & atistic & 57.04842 & Durbin -Watson stat & 2.008195 \\
\hline & -Statistic) & 0.000214 & & \\
\hline
\end{tabular}




\begin{tabular}{|c|c|c|c|c|}
\hline \multicolumn{3}{|c|}{$\begin{array}{c}\text { Series } 5 \text { : LN(ADRE) LN(OIL) } \\
\text { Dependent Variable : D(ADCT) } \\
\text { Sample } 4392 \\
\text { Included observations : } 389 \text { after } \\
\text { adjustments }\end{array}$} & \multicolumn{2}{|c|}{$\begin{array}{c}\mathrm{D}(\mathrm{ADRE})=\mathrm{C}(1) \times(\mathrm{ADRE}(-1)- \\
0.921468756309 \times \mathrm{OIL}(-1)-0.00458436384047) \\
+\mathrm{C}(2) \times \mathrm{D}(\mathrm{ADRE}(-1))+\mathrm{C}(3) \times \mathrm{D}(\mathrm{ADRE}(-2))+ \\
\mathrm{C}(4) \times \mathrm{D}(\mathrm{OIL}(-1))+\mathrm{C}(5) \times \mathrm{D}(\mathrm{OIL}(-2))+\mathrm{C}(6)\end{array}$} \\
\hline & Coefficient & Std. Error & t-statistic & Prob. \\
\hline $\mathrm{C}(1)$ & -0.653377 & 0.084951 & -7.691251 & 0.0000 \\
\hline $\mathrm{C}(2)$ & -0.229085 & 0.071964 & -3.183330 & 0.0016 \\
\hline $\mathrm{C}(3)$ & -0.168731 & 0.052516 & -3.212912 & 0.0004 \\
\hline $\mathrm{C}(4)$ & -0.372026 & 0.082838 & -4.491029 & 0.0000 \\
\hline$C(5)$ & -0.251818 & 0.071251 & -3.534258 & 0.0005 \\
\hline$C(6)$ & $-1.40 \mathrm{E}-05$ & 0.002732 & -0.005108 & 0.9959 \\
\hline \multicolumn{2}{|c|}{ R-Squared } & 0.440210 & Mean Dependent var & -0.000140 \\
\hline \multicolumn{2}{|c|}{ Adjusted R-squared } & 0.432902 & S.D. dependent var & 0.071539 \\
\hline \multicolumn{2}{|c|}{ S.E. of regression } & 0.053873 & Akaike info criterion & -2.989079 \\
\hline \multicolumn{2}{|c|}{ Sum square residual } & 1.111571 & Schwarz criterion & -2.927945 \\
\hline \multicolumn{2}{|c|}{ Log likelihood } & 587.3759 & Hannan- Quinn Criterion & -2.964843 \\
\hline \multicolumn{2}{|c|}{ F-statistic } & 60.23698 & Durbin -Watson stat & 2.047042 \\
\hline \multicolumn{2}{|c|}{ Prob ( F-Statistic) } & 0.000000 & & \\
\hline
\end{tabular}

\subsection{Coefficients Diagnostic}

Wald test is a way to find out if explanatory variables in a model, in the present study - C(4) and C(5) ( see Table 4 ), are significant. Their significance here refers to their contributions to the model. And if their contributions are not found to be significant then they can be deleted without affecting the model in any meaningful way. Coefficient $\mathrm{C}(4)$ and $\mathrm{C}(5)$ are linked by one lag and two lags to $\mathrm{LN}(\mathrm{OIL})$ respectively. Thus, the null hypothesis is -

Null Hypothesis $\mathrm{C}(4)=\mathrm{C}(5)=0$

For all series, the null hypothesis is rejected since p values are less than $5 \%$ for both F-Statistic and Chi-square $(\chi)$ Statistic which signify that $C(4) \neq C(5) \neq 0$. Thus, the lag values of the dependent variables are found to be significant in estimating the return of indices.

Table 5. Coefficient Diagnostic - Wald Test

\begin{tabular}{ccccc}
\hline Series & Test Statistic & Value & Df & Prob. \\
\hline Series 1 :LN(ADXG) & F- Statistic & 39.26573 & $(2,383)$ & 0.0000 \\
LN(OIL) & Chi-square & 78.53146 & 2 & 0.0000 \\
Series 2: LN(ADBF) & F- Statistic & 28.70844 & $(2,383)$ & 0.0000 \\
LN(OIL) & Chi-square & 57.41688 & 2 & 0.0000 \\
Series 3: LN(ADCT) & F- Statistic & 18.70477 & $(2,383)$ & 0.0000 \\
LN(OIL) & Chi-square & 37.40954 & 2 & 0.0000 \\
Series 4: LN(ADEG) & F- Statistic & 30.32166 & $(2,383)$ & 0.0000 \\
LN(OIL) & Chi-square & 60.64333 & 2 & 0.0000 \\
Series 5: LN(ADRE) & F- Statistic & 11.41926 & $(2,383)$ & 0.0000 \\
LN(OIL) & Chi-square & 22.83851 & 2 & 0.0000
\end{tabular}

\subsection{Residual Diagnostic}

The Breusch-Godfrey serial correlation LM test is a test for autocorrelation in the errors in a regression model. The presence of serial correlation would mean that sub-optimal model estimates of parameter have been obtained. Since the VEC models developed (Table 4) for five series include two lag values of $\mathrm{LN}(\mathrm{OIL})$ as independent variables, it is necessary to check for serial correlation up to order ' $p$ '. Since this has used two lags, null hypothesis is that 'there is no serial correlation at up to 2 lags'. Table 6 provides the test statics. It is found that null hypothesis of 'no serial 
correlation' is not rejected with respect to Series 1: LN(ADXG) and LN(OIL), Series 2: LN(ADBF) and LN(OIL) and Series 5: LN(ADRE) and LN(OIL). However, presence of serial correlation is found in cases of Series 3: $\mathrm{LN}(\mathrm{ADCT})$ and $\mathrm{LN}(\mathrm{OIL})$, and Series 4: LN(ADEG) and LN(OIL). Thus, the VEC model developed for these series may not be a proper fit because of model specification error.

Table 6. Residual Diagnostic : Serial Correlation LM Test

Breusch -Godfrey Serial Correlation LM Test

Noll Hypothesis : No serial Correlation at up to 2 lags

\begin{tabular}{ccccc}
\hline Series & Test Statistic & Value & Df & Prob. \\
\hline Series 1 :LN( ADXG) LN(OIL) & F-Statistic & 1.690120 & $(2,381)$ & 0.1859 \\
& Obs*R-Squared & 3.420865 & 2 & 0.1808 \\
Series 2: LN(ADBF) LN( OIL) & F-Statistic & 1.496995 & $(2,381)$ & 0.2251 \\
& Obs*R-Squared & 3.033022 & 2 & 0.2195 \\
Series 3: LN(ADCT) LN( OIL) & F-Statistic & 5.454384 & $(2,381)$ & 0.0046 \\
& Obs*R-Squared & 10.82780 & 2 & 0.0045 \\
Series 4: LN(ADEG) LN( OIL) & F-Statistic & 4.161337 & $(2,381)$ & 0.0163 \\
& Obs*R-Squared & 8.315776 & 2 & 0.0156 \\
Series 5: LN(ADRE) LN( OIL) & F-Statistic & 2.699964 & $(2,381)$ & $\mathbf{0 . 0 6 8 5}$ \\
& Obs*R-Squared & 5.436265 & 2 & 0.0660 \\
\hline
\end{tabular}

\subsection{Stability Diagnostic}

Stability diagnostic analysis is carried out using recursive estimates (CUSUM Test). The test result is presented in Figure 4. The CUSUM line (marked in blue) falls within 5\% significance level reflected by upper and lower boundaries (marked in red). This shows that the specified VEC models of the five series are stable.

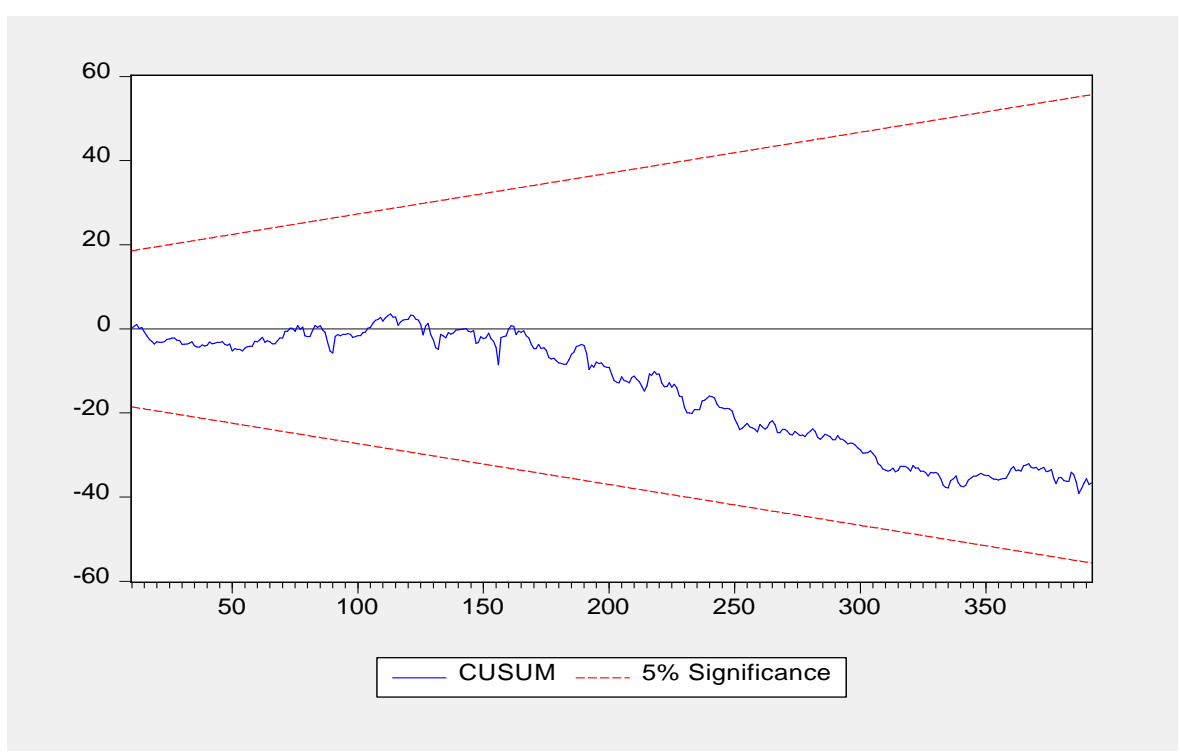

Series 1. LN( ADXG) LN(OIL) 


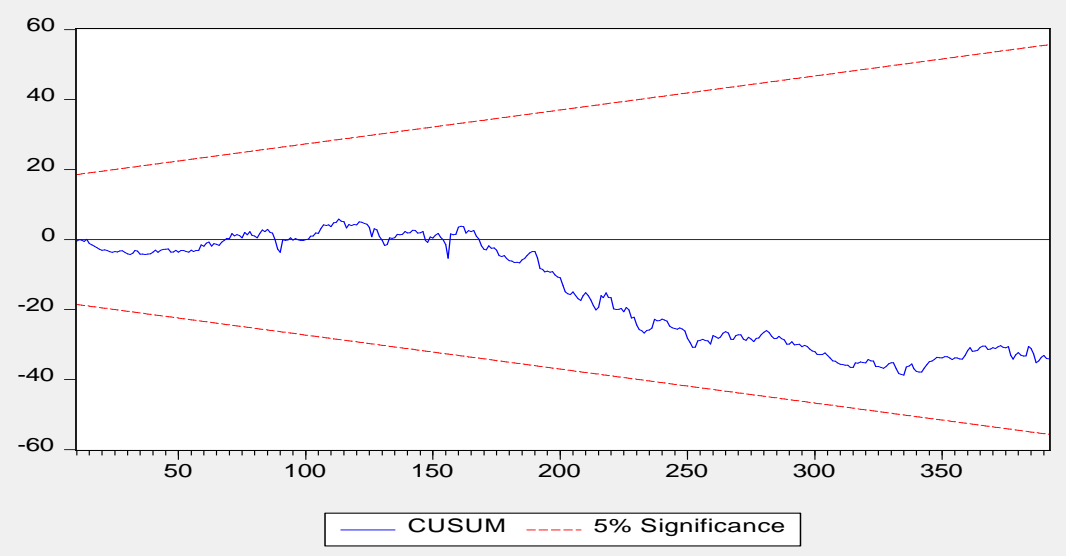

Series 2. LN(ADBF) LN( OIL)

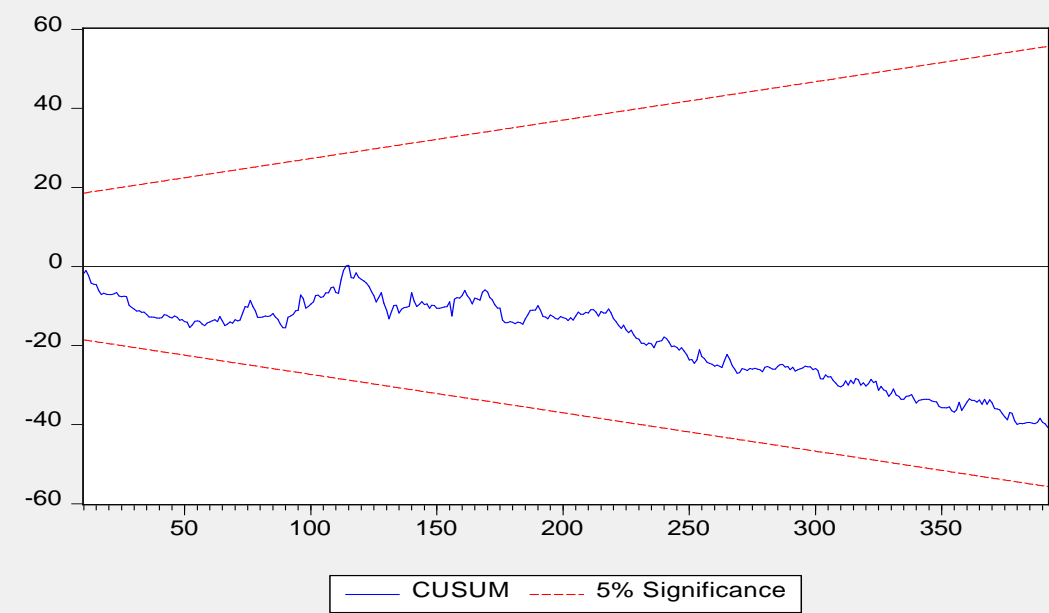

Series 3. LN(ADCT) LN( OIL)

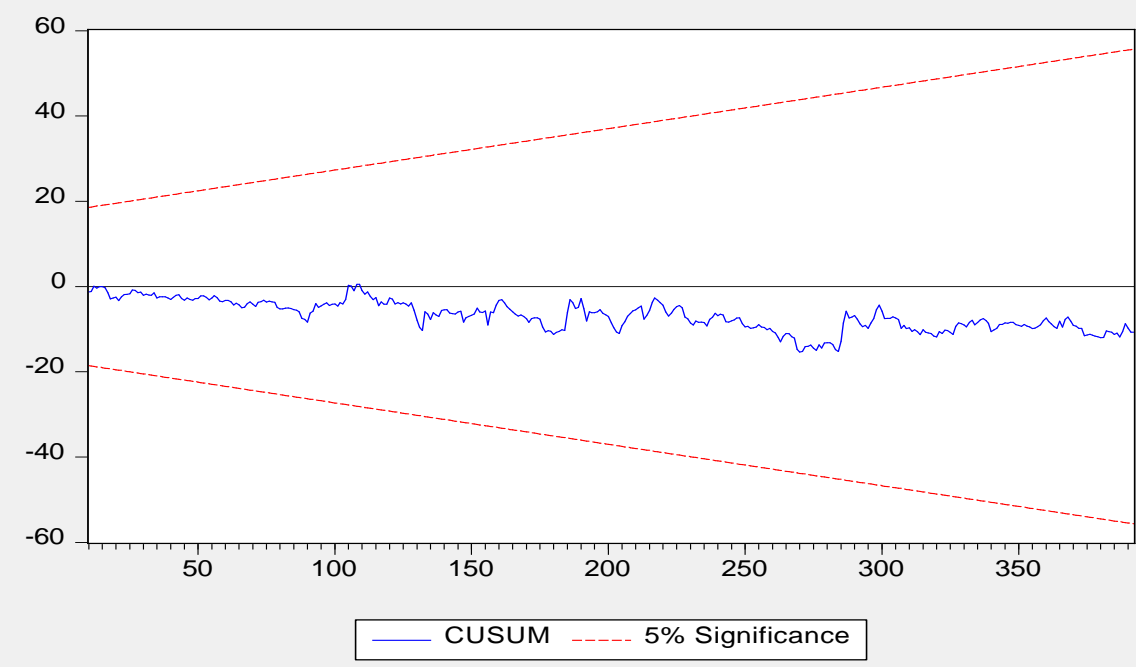

Series 4. LN(ADEG) LN( OIL) 


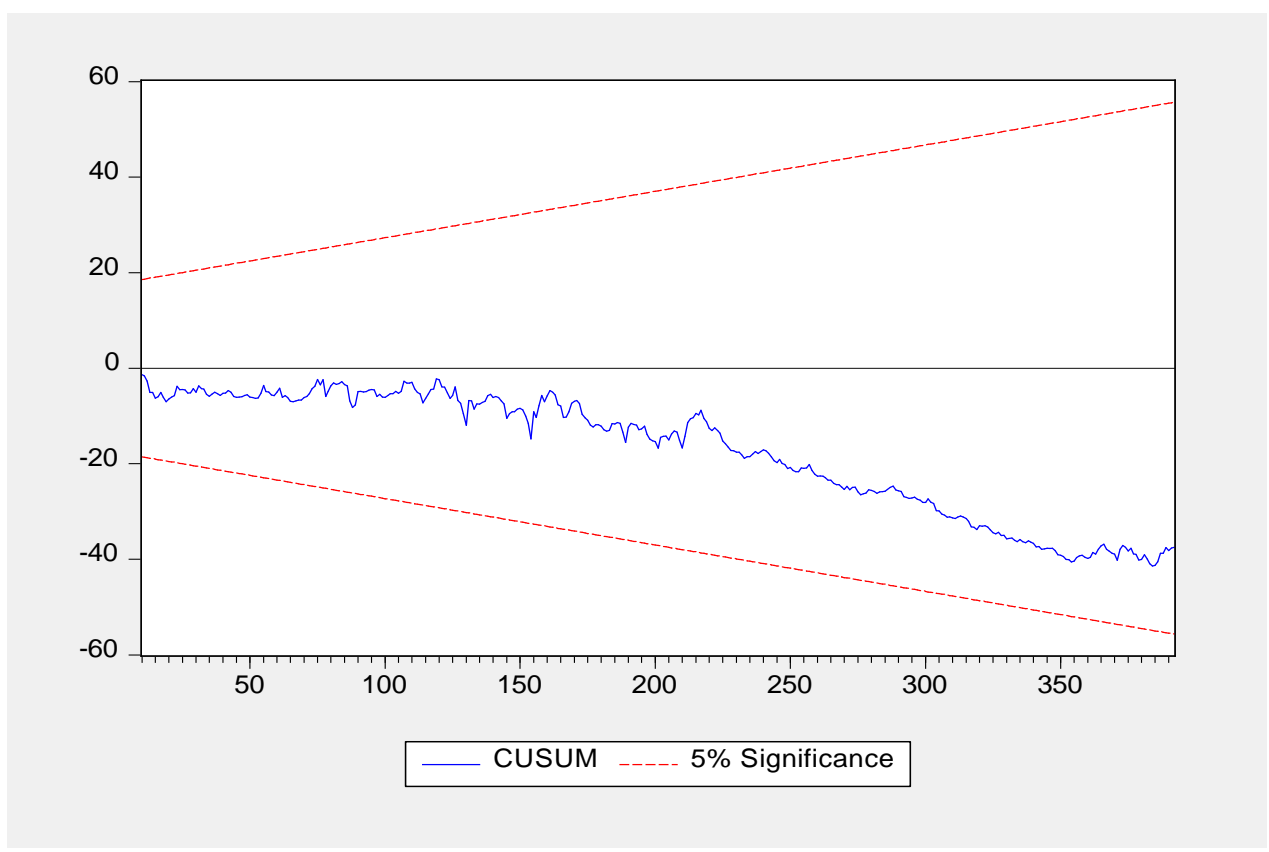

Series 5. LN(ADRE) LN( OIL)

Figure 4. Recursive estimates (OLS Only) : CUMSUM

Based on the outputs of VEC model and corresponding coefficient diagnostics, residual diagnostics and stability diagnostics it is concluded that null hypothesis that ' Changes in UAE Stock market returns are independent of oil price changes in the aftermath of the 2014 oil price shock' is rejected. Findings of the study are in consonance with the previous studies Maghyereh and Al -Kandari ( 2007), Al Arouri et al (2010), Alhayki ( 2014), and Alqattan and Alhayky (2016).

\subsection{Granger Causality Tests}

Finally, Granger Causality Tests are carried out to analyze whether one time series, weekly WTI prices in this study, is useful in forecasting another i.e. stock returns and vice versa. In the context of this study, it states that changes in weekly WTI prices "granger causes" (i.e., contain information that helps predicting) weekly return of stock indices in UAE other than lagged value of indices return. Results of Granger Causality Tests of five series are presented in Table 7 which shows that LN(OIL) "granger causes" LN(ADXG), LN (ADBF), LN(ADCT), LN(ADEG) and LN(ADRE). But stock returns do not Granger cause change in oil price which is consistent with a-priori knowledge.

Accordingly, it is found that returns of stock indices in the UAE are cointegrated with oil price changes. Sectoral indices relating to Banking and Real Estate are also influenced by changes in oil prices. It appears logical as these two industries are primarily driven by oil revenue surplus. However, VEC models with respect to manufacturing and energy sectors, although showing cointegration with change in oil prices and satisfying coefficient diagnostic and stability diagnostic tests, the specified models are subjected to presence of serial correlation and so are not reliable. Further studies are not conducted to identify causes of serial correlation in these two series. 
Table 7. Pairwise Granger Causality Tests

\begin{tabular}{|c|c|c|c|c|}
\hline \multicolumn{5}{|l|}{ Sample 1392 Lag 2} \\
\hline \multicolumn{5}{|l|}{ Null Hypothesis: } \\
\hline LN(OIL) does not Granger cause LN(ADXG) & 390 & 11.9810 & 9E-06 & Rejected \\
\hline LN(ADXG) does not Granger cause LN(OIL) & & 0.56085 & 0.5712 & Not Rejected \\
\hline $\begin{array}{c}\text { Series } 2: \quad \mathbf{N}(\boldsymbol{A D B F}), \mathbf{L N}(\boldsymbol{O I L}) \\
\text { Sample } 1392 \mathrm{Lag} 2\end{array}$ & \multicolumn{3}{|c|}{ Sample 1392 Lag 2} & \\
\hline \multicolumn{5}{|l|}{ Null Hypothesis: } \\
\hline LN(OIL) does not Granger cause LN(ADBF) & 390 & 9.96551 & $6 \mathrm{E}-05$ & Rejected \\
\hline LN(ADBF) does not Granger cause LN(OIL) & & 0.56507 & 0.5688 & Not Rejected \\
\hline $\begin{array}{c}\text { Series 3: } \mathbf{L N}(\boldsymbol{A D C T}), \mathbf{L N}(\mathbf{O I L}) \\
\text { Sample } 1392 \mathrm{Lag} 2\end{array}$ & Observations & F-Statistic & Prob. & \\
\hline \multicolumn{5}{|l|}{ Null Hypothesis: } \\
\hline LN(OIL) does not Granger cause LN(ADCT) & 390 & 11.9810 & 9.E-06 & Rejected \\
\hline LN(ADCT) does not Granger cause LN(OIL) & & 0.56085 & 0.5712 & Not Rejected \\
\hline $\begin{array}{c}\text { Series } 4: \quad \mathbf{L N}(\boldsymbol{A D E G}), \mathbf{L N}(\boldsymbol{O I L}) \\
\text { Sample } 1392, \text { Lag } 2\end{array}$ & \multicolumn{3}{|c|}{ Sample 1 392, Lag 2} & \\
\hline \multicolumn{5}{|l|}{ Null Hypothesis: } \\
\hline LN(OIL) does not Granger cause LN(ADEG) & 390 & 11.9810 & 9.E-06 & Rejected \\
\hline LN(ADEG) does not Granger cause LN(OIL) & & 0.56085 & 0.5712 & Not Rejected \\
\hline $\begin{array}{c}\text { Series 5: } \quad \boldsymbol{L N}(\boldsymbol{A D R E}), \boldsymbol{L N}(\boldsymbol{O I L}) \\
\text { Sample } 1392 \mathrm{Lag} 2\end{array}$ & \multicolumn{3}{|c|}{ Sample 1392 Lag 2} & \\
\hline \multicolumn{5}{|l|}{ Null Hypothesis: } \\
\hline LN(OIL) does not Granger cause LN(ADRE) & 390 & 11.9810 & 9.E-06 & Rejected \\
\hline LN(ADRE) does not Granger cause LN(OIL) & & 0.56085 & 0.5712 & Not Rejected \\
\hline
\end{tabular}

The result of the study signifies that performance of stock market in the UAE is continued to be influenced by oil price volatility. It may be mentioned that proportion of market capitalization of energy sector companies listed on ADX are not substantial. A major portion of the market capitalization is contributed by companies belonging to banking, insurance and financial services. Thus, despite increased contribution of non-oil sector in the GDP, the stock market performance is not decoupled from oil price volatility. This may be because of predominance of oil price linked government revenue. Although contribution of non-oil sectors has increased, the structure of UAE government revenue has not significantly changed. Value added tax and income from other non-oil sources are not significant. Thus, adverse change in oil price would continue to impact the government revenue and consequently government spending for development of non-oil sectors. On the other hand, increased oil price would strengthen budget surplus and improve government spending for the development of non-oil sectors.

\section{Concluding Remarks}

The result of this study has important policy implications that along with non-oil diversification of GDP it is equally important to achieve non-oil diversification of government revenue. Perhaps introduction of value added tax as an alternative source of revenue is not sufficient as a means of deriving government revenue from non-oil sector. A recent IMF paper [Olumuyiwa et al (2018)] states MENAP oil exporters are benefitted from subsidy reform, with 
spending on subsidies reduced while capital expenditure protected, with minimum reduction of one percent of GDP. While tax revenues have only delivered 0.3 percent of GDP in the fiscal balancing process. The UAE performed little better as the VAT collection accounts for about 1.7 per cent of nominal GDP. The IMF paper [20] also highlights that total tax revenue collection in the MENAP region is significantly less than in other emerging market economies. The biggest discrepancy is that non-oil tax revenues represent less than 10 percent of GDP in MENAP oil exporters against more than 20 percent of GDP in emerging market economies. In the UAE, taxation reform including introduction of corporate tax and even low level of personal income tax might change the GDP composition as against the present dependence on fees and stamp duties.

Second, developing non-oil manufacturing sector is difficult because of demographic constraint. The UAE economy is mostly driven of migrant work force. Development of manufacturing sector would necessitate deployment of large migrant work force which impact demographic balance. Thus even taxation reform may have limited impact on decoupling the oil dependency of the economy.

Third, the ADXG is not a broad based index and the sectoral indices have equally narrower base. They get easily influenced by oil price volatility. The stock market indices may not reflect the economic performance of the companies. The narrow investor base of the ADXG also causes a psychological barrier to decoupling from oil shocks. Thus it is important to study impact of oil price volatility on profitability of non-oil sector companies. The impact Saudi market spill -over effect has not been studied in this paper.

This study did not include Dubai Financial Market data because of its distinguishing non-oil characteristics. However, it has been observed that weekly stock index returns during the study period are cointegrated with oil price volatility. Though oil linked sources do not contribute much to state Government revenue, this is perhaps because of the linkage that exists between level of spending of the Federal Government and the level of oil price.

This study did not conduct segregated analysis of the impact of direction and size of oil price change on stock returns which would be covered in future research.

\section{References}

Alqattan, A. A. \& Alhayky, A. (2016). Impact of oil prices on stock markets: Evidence from Gulf Cooperation Council (GCC) financial markets. Amity Journal of Finance, 1(1), 1-8. https://doi.org/10.1002/ijfe.443

Alhayki, Z. J. (2014). The dynamic co-movements between oil and stock market returns in the case of GCC countries. Journal of Applied Finance and Banking, 4(3), 103-113.

Arouri, M. E. H. \& Rault, C. (2012). Oil prices and stock markets in GCC countries: Empirical evidence from panel analysis. International Journal of Finance and Economics, 17(3), 242-253. https://doi.org/10.1002/ijfe.443

Arouri, M. E. H. \& Fouquau, J. (2009). On short-term influence of oil price changes on stock markets in GCC countries: Linear and nonlinear analyses. Economic Bulletin, 29(2), 795-804.

Arouri, M. E. H., Lahiani, A. \& Bellalah, M. (2010). Oil price shocks and stock market returns in oil-exporting countries: The case of GCC countries. International Journal of Economics and Finance, 2(5), 132-139. https://doi.org/10.5539/ijef.v2n5p132

Basher, S. A. \& Sadorsky, P. (2006). Oil price risk and emerging stock markets. Global Finance Journal, 17(2), 224-251. https://doi.org/10.1016/j.gfj.2006.04.001.

Cheikh, N. B., Naceur, S. B., Kanaan, O. \& Rault, C. (2018). Oil prices and GCC stock markets: New evidence from smooth transition models. IMF Working Paper, WP/18/98.

Chen, N. F., Roll, R. \& Ross, R. (1986). Economic forces and the stock market. Journal of Business, 59(3), 383-403. https://doi.org/10.1086/296344.

Dotsey, M. \& Reid, M. (1992). Oil shocks, monetary policy \& economic activity. Federal Reserve Bank of Richmond Economic Review, 78(4), 14-27.

Dutta, A., Nikkinen, J. \& Rothovius, T. (2017). Impact of oil price uncertainty on Middle East and African stock markets. Energy, 123, 189-197. https://doi.org/10.1016/j.energy.2017.01.126.

Feride O. (2015) Oil Price Shocks - Macro economy relationship in Turkey, Asian Economic and Financial Review, 2015, 5(5), 846-857. 
Ghosh, T.P. (2017). Oil dependency of GCC stock markets: Co-integration of GCC stock market indices and oil price. International Journal of Business and Management, 12(1), 188-200. https://doi.org/10.5539/ijbm.v12n1p188.

Hamilton, J. D. (1983). Oil and the macroeconomy since World War II. Journal of Political Economy, 91(2), 228-248. https://doi.org/10.1086/261140

Hamilton, J. D. (1996). This is what happened to the oil price-macroeconomy relationship. Journal of Monetary Economics, 38(2), 215-220.

Hamilton, J. D. (2009). Causes and consequences of the oil shock of 2007-08. Brookings Papers on Economic Activity, Economic Studies Program, The Brookings Institution, 40(1), 215-283. https://doi.org/10.3386/W15002

Hamilton, J. D. (2013). Historical oil shocks. Routledge Handbook of Major Events in Economic History, Routledge, 239-265.

Hammoudeh, S. \& Li, H. (2005). Oil sensitivity and systematic risk in oil-sensitive stock indices. Journal of Economics and Business, 57(1), 1-21.

Hooker, M. A. (1996). What happened to the oil price-macroeconomy relationship?. Journal of Monetary Economics, 38(2), 195-213. https://doi.org/10.1016/S0304-3932(96)01281-0

Hung, R. D., Masulis, R. W. \& Stoll, H. R. (1996). Energy shocks and financial markets. Journal of Futures Markets: Futures, Options \& Other Derivative Products, 16(1), 1-27.

IMF (2018). World Economic and Financial Surveys, Middle East and Central Asia, Chapter 4, 39-51.

Jones, C. M. \& Kaul, G. (1996). Oil and the stock markets. The Journal of Finance, 51(2), 463-491.

Maghyereh A. and Al-Khandari A (2007). Oil prices and stock markets in GCC countries: new evidence from nonlinear cointegration analysis, Managerial Finance, 33(7), 449-460. https://doi.org/10.1108/03074350710753735

Mork, K. A. (1989). Oil and the macroeconomy when prices go up and down: An extension of Hamilton's results. Journal of Political Economy, 97(3), 740-744. https://doi.org/10.1086/261625.

Mork, K. A., Olsen, O. \& Mysen, H. T. (1994). Macroeconomic responses to oil price increases and decreases in seven OECD countries. The Energy Journal, 15(4), 19-35.

Papapetrou, E. (2001). Oil price shocks, stock market, economic activity and employment in Greece. Energy Economics, 23(5), 511-532. https://doi.org/10.1016/S0140-9883(01)00078-0.

Olumuyiwa S.A., Shahid S. \& Zhu L. (2018). Saudi Arabia's growth and financial spillovers to other GCC countries: An empirical analysis, IMF Working Paper, WP/18/278.

Olumuyiwa S.A, Botir B \& Zhu L (2017). The Economic outlook and policy changes in GCC countries, IMF Staff Paper.

Organization of Oil Exporting Countries (2018) Annual Report 2018.

Ozturk, F. (2015). Oil price shocks - Macro economy relationship in Turkey. Asian, Economic and Financial Review, $5(5), 846-857$.

Sadorsky, P. (1999). Oil price shocks and stock market activity. Energy Economics, 21(5), 449-469. https://doi.org/10.1016/S0140-9883(99)00020-1.

Sonenshine, R. \& Cauvel, M. (2017). Revisiting the effect of crude oil price movements on US stock market returns and volatility. Modern Economy, 8(5), 753-769. https://doi.org/10.4236/me.2017.85053.

Vohra, R. (2017). The impact of oil prices on GCC economies. International Journal of Business and Social Science, $8(2), 7-14$.

UAE Central Bank (2018). Annual 2017 https://www.centralbank.ae/sites/default/files/2018-10/CBUAEAnnualReport-2017_En.pdf UAE Central Bank (2019). Annual Report 2018 https://www.centralbank.ae/sites/default/files/2019-05/Central\%20Bank\%20-\%20Annual\%20Report\%20-\%202 018.pdf 
UAE Central Bank \& Federal Competitiveness and Statistical Authority (2018) Annual Report 2018. http://fcsa.gov.ae/en-us

UAE Ministry of Economy (2018). Annual Economic Report 2018, $26^{\text {th }}$ Edition.

\section{Notes}

Note 1. Gulf Cooperation Council (GCC) countries (comprising of Saudi Arabia, Kuwait, the United Arab Emirates, Qatar, Bahrain and Oman) are a political and economic alliance. These economies are considered as 'oil dependent' despite planned effort of diversification to non-oil sectors. Of the GCC countries, Saudi Arabia, Kuwait, and the United Arab Emirates together produced 16,403 tb/d in 2018 which was 50.34\% of OPEC crude oil production for that year (2014: 50.83\%; 2015: 50.62\%; 2016: 50.41\%; 2017: 48.66\%) [ Organization of Oil Exporting Countries (2018)].

Note 2. United Arab Emirates (UAE) holds the seventh-largest proved reserves of oil in the world at 97.8 billion barrels, with the majority of reserves located in Abu Dhabi (approximately 94 percent). This is about $7 \%$ of World's total reserve. The United Arab Emirates (UAE) sources most of its oil from the Zakum field, which has an estimated 66 million barrels. It is ranked as $8^{\text {th }}$ oil producing country with a production of 3,106,077 bbl/day. The State owned ADNOC is world's $12^{\text {th }}$ largest oil producer. [UAE Central Bank (2018)].

Note 3. ADX General Index $(A D X G)$ : Abu Dhabi Stock Exchange (ADX) General Index tracks the performance of all listed equities. ADX was established on 15th of November 2000. It has the authority to establish centers and branches outside the Emirate of Abu Dhabi, and so far it has done so in Al Ain, Zayed City, Fujairah, Ras Al Khaimah and Sharjah. As of 31 July 2019, there are 70 listed companies having a combined market capitalization of AED 520 billion (US\$ 141.56 billion). [www.adx.ae]

Note 4. MENAP oil exporters include Algeria, Bahrain, Iran, Iraq, Kuwait, Libya, Oman, Qatar, Saudi Arabia, the United Arab Emirates, and Yemen. 


\section{Appendix A}

[ Ref. Section 3.5.]

Johansen cointegration test is conducted on five series under study - Series 1: LN (ADXG) LN (OIL), Series 2 LN (ADBF) LN (OIL), Series 3 LN ( ADCT) LN(OIL), Series 4 LN (ADEG) LN (OIL) and Series 5 LN ( ADRE) LN (OIL).

Null Hypothesis : There is no co-integrating equation or at most 1 cointegrating equation are rejected. In all pairs, both Trace test and maximum Eigen value tests indicated 2 cointegrating equations

\section{Cointegration test result}

Unrestricted Co-integration Rank test (Trace)

\begin{tabular}{|c|c|c|c|c|c|}
\hline Series & $\begin{array}{l}\text { Hypothesized } \\
\text { No of } C E(s)\end{array}$ & Eigenvalue & $\begin{array}{c}\text { Trace } \\
\text { Statistic }\end{array}$ & $\begin{array}{l}0.5 \text { Critical } \\
\text { Value }\end{array}$ & Prob. ** \\
\hline \multirow[t]{2}{*}{$1: \mathrm{LN}(\mathrm{ADXG}) \quad \mathrm{LN}(\mathrm{OIL})$} & None** & 0.324276 & 235.9029 & 15.49471 & 0.0000 \\
\hline & At most $1 *$ & 0.193025 & 83.42619 & 3.841466 & 0.0000 \\
\hline \multirow[t]{2}{*}{ 2: LN (ADBF) LN (OIL) } & None** & 0.397621 & 314.5957 & 15.49471 & 0.0000 \\
\hline & At most $1^{*}$ & 0.259025 & 116.9173 & 3.841466 & 0.0000 \\
\hline \multirow[t]{2}{*}{ 3: LN (ADCT) LN (OIL } & None** & 0.326398 & 277.2153 & 15.49471 & 0.0000 \\
\hline & At most $1^{*}$ & 0.270717 & 123.1203 & 3.841466 & 0.0000 \\
\hline \multirow[t]{2}{*}{ 4: LN (ADEG) LN (OIL) } & None** & 0.295325 & 217.8210 & 15.49471 & 0.0000 \\
\hline & At most $1^{*}$ & 0.189362 & 81.66402 & 3.841466 & 0.0000 \\
\hline \multirow[t]{2}{*}{ 5. LN (ADRE) LN(OIL) } & None** & 0.354948 & 300.7299 & 15.49471 & 0.0000 \\
\hline & At most $1^{*}$ & 0.282999 & 129.7443 & 3.841466 & 0.0000 \\
\hline
\end{tabular}

Trace test indicated 2 cointegrating eqn(s) at the 0.05 level

*Denotes rejection of the hypothesis at the 0.05 level

** Mackinnon-Haugh-Michelis (1999) p-values

Unrestricted Cointegration Rank test (Maximum Eigenvalue)

\begin{tabular}{|c|c|c|c|c|c|}
\hline Series & $\begin{array}{c}\text { Hypothesized } \\
\text { No of } C E(s)\end{array}$ & Eigenvalue & $\begin{array}{c}\text { Max-Eigen } \\
\text { Statistic }\end{array}$ & $\begin{array}{c}0.5 \text { Critical } \\
\text { Value }\end{array}$ & Prob. ** \\
\hline \multirow[t]{2}{*}{$1:$ LN (ADXG) LN (OIL) } & None** & 0.324276 & 235.9029 & 14.26460 & 0.0000 \\
\hline & At most $1^{*}$ & 0.193025 & 83.42619 & 3.841466 & 0.0000 \\
\hline \multirow[t]{2}{*}{ 2: LN (ADBF) LN (OIL) } & None** & 0.397621 & 197.6785 & 15.49471 & 0.0000 \\
\hline & At most $1 *$ & 0.259025 & 116.9173 & 3.841466 & 0.0000 \\
\hline \multirow[t]{2}{*}{ 3: LN (ADCT) LN (OIL } & None** & 0.326398 & 154.0950 & 14.26460 & 0.0000 \\
\hline & At most $1^{*}$ & 0.270717 & 123.1203 & 3.841466 & 0.0000 \\
\hline \multirow[t]{2}{*}{ 4: LN (ADEG) LN (OIL) } & None** & 0.295325 & 136.1570 & 14.26460 & 0.0000 \\
\hline & At most $1 *$ & 0.189362 & 81.66402 & 3.841466 & 0.0000 \\
\hline \multirow[t]{2}{*}{ 5. LN (ADRE) LN(OIL) } & None** & 0.354948 & 152.4768 & 14.26460 & 0.0000 \\
\hline & At most $1 *$ & 0.282999 & 129.7443 & 3.841466 & 0.0000 \\
\hline
\end{tabular}

Max-eigenvalue test indicated 2 cointegrating eqn(s) at the 0.05 level

*Denotes rejection of the hypothesis at the 0.05 level

** Mackinnon-Haugh-Michelis (1999) p-values 